\title{
МОРФОЛОШКЕ КАРАКТЕРИСТИКЕ ГЕНИТИВА И ЛОКАТИВА, ДАТИВА И ИНСТРУМЕНТАЛА МНОЖИНЕ ИМЕНИЦА У ПАШТРОВСКИМ ИСПРАВАМА (16. И 17. ВИЈЕК)
}

\begin{abstract}
Предмет нашег рада јесу двојинско-множинска укрштања у ГЛ, односно ДИ множине у Паштровским исправама 16. и 17. вијека. Паштровске исправе пружају изузетно занимљив материјал за језичка истраживања, представљају значајну карику за употпуњавање историјске и територијалне слике српског језика. Према нашем корпусу, у 16. и 17. вијеку, у Паштровским исправама заступљена је једнакост генитива и локатива множине, односно датива и инструментала. Једнакост није доведена до краја, али су евидентни процеси једначења ових падежа, условљени двојинском једнакошћу и губљењем двојине као синтаксичко-семантичке категорије.

Кључне ријечи: Паштровске исправе, генитив и локатив множине, датив и инструментал множине, говор Паштровића, прерасподјела наставака, падежни синкретизам
\end{abstract}

1. Паштровске исправе пружају изузетно занимљив материјал за језичка истраживања, представљају значајну карику за употпуњавање историјске и територијалне слике српског језика. Историјске прилике условиле су умногоме особен језички развој, у језику се често огледају архаичне црте, или развијају посебне иновације, што се очитује и у језику Исправа. С обзиром на то представљају грађу, једну од најзначајнијих у српском језичком насљеђу у периоду 16-17/18. вијека, јер је из овог периода најмање сачуваних споменика писаних српским народним језиком. Најбогатија збирка докумената чува се у манастиру Прасквица, према нашој евиденцији докумената 16-19. вијека је око 300, а из 19. вијека 50 исправа. Највећи број (можда око двије трећине докумената који се овдје чувају) односи се на манастир Градиште.

*jelicast@yahoo.com 
Извршили смо фотографисање ове збирке, а с обзиром на то да је корпус обиман, за овај рад ограничили смо се на најстарији дио, на 16. и 17. вијек. Како смо извршили фотографисање и Паштровских исправа из Државног архива Цетиње и Будва, то смо корпус проширили и овим документима. Из 16. вијека за овај рад рашчитали смо 49 исправа, ексцерпирали и описали грађу (манастир Прасквица 30 исправа, ДАЦ 19); а из 17. вијека 140 исправа (Прасквица 115; ДАЦ 20; ДАБ 5). Неке од њих су прилично оштећене тако да је читљив само дио текста.

2. Двојинска једнакост генитива и локатива на једној, односно датива и инструментала на другој страни, утицала је, након губљења двојине као синтаксичко-семантичке категорије, у почетној фази, на једначење ових падежа у множини, нарочито у појединим дијалектима, што је нарочито захватило зетско-рашки дијалекат, којем припада и говор Паштровића.

2.1. Једнакост генитива и локатива двојине утицала је на то да се од најстаријих времена у српском језику почиње јављати једнакост ових падежа у множини. Јављају се како облици генитива у локативној сфери употребе, тако и обрнуто. Ова једнакост нашла је одраза у Паштровским исправама.

Формирање наставка - $a$ у Гмн. једно је од најсложенијих проблема у историји српског језика. У вези са овим генитивним наставком постоје различита мишљења, тек овај проблем није, рекло би се, ни данас разријешен. Наставак - $a$ може бити полугласничког поријекла (тј. може бити из Лмн. $-b x ъ /-b x z$, или пак Гмн. -b/-z) или етимолошког (из Лмн. $-a x ъ /$, или $-a /-a-$ из односа -ам/-ами/-ама). Једни су (Шафарик [видјети, Симић 2002: 13], Даничић [Даничић 1858], Мајков [Симић 2002: 14-15], Решетар [Решетар 1907], Ивић [Брозовић-Ивић 1988: 24], Младеновић [Младеновић 2008: 102-110]) у генитивном наставку - $a$ видјели стари полугласник. Други су у наставку - $a$ видјели етимолошко $a$ (дакле, неполугласничко поријекло), објашњавајући га као $a$ из система, углавном као покретно $a$. Петар Скок (Симић 2002: 27) овај наставак доводи у везу са придјевско-замјеничким - $а$ у -им/-има и сл. Слично овом и Гојко Ружичић сматра да поријекло наставка - $\hat{a}$ треба тражити код покретног прилошког - $а$ (Ружичић 1926: 214-232), са чиме се Белић није сложио, иако у овом наставку такође види покретно $a$ (етимолошко), али не прилошко него покретно $a$ настало од двојинско-множинских укрштања ДИ именица, од односа -ам/-ами/-ама (Белић 2000: 360-361).

Према трећима, условно речено, наставак Гмн. објашњава се двојинско-множинским укрштањем генитива и локатива, што је процес посвједочен на ширем дијалекатском подручју и у споменичкој грађи. Ова једнакост ће бити посебно интересантна за наш корпус и језичке процесе који су захватили овај дијалекатски ареал. Овом проблему посветио је пажњу и Белић. Он за косовско-ресавске говоре констатује да је облик Гмн. пренесен на Лмн.

Како налазимо код Стевановића (Стевановић 1935: 66), а и у дијалектолошкој грађи, један (немали) број говора зетско-рашког типа има изједначен

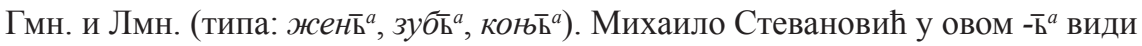
вокалски дио локативнога -ьхъъ, -ъхъ „старих $\breve{l}$-, $\breve{u}$ - и консонантских основа... који се, изузимајући... групу женског рода без наставка у једнини... раширио 
на све остале промене" (Стевановић 1935: 34). Стевановић сматра да је наставак у Гмн. (било - $а$, било -Б) посљедица укрштања са локативом. Према Симићу: „У новом облику же̄на̂, же́н $\bar{a}$ (тј. Гмн. - Ј. С.), огледају се престилизоване особине же̂н, женӓх и сл. - под утицајем процеса парадигматске нивелације: огледа се, дакле, међусобна борба посебних облика, на једној страни, и 'притисак' система, на другој” (Симић 2002: 35). Радоје Симић, у одговору на питање, ,...да ли је у Гмн. $-\bar{a}$ оправданије видети етимолошко $a$ или полугласник?”, закључује: „Ако (а) упоредимо - $\bar{a}$ са 'зетским' - ${ }^{a}$ и ђаковачким -b, (б) размотримо све услове његовог настанка, (в) укалкулишемо овамо и начине 'вокализације' полугласника̂, - можемо са високом вероватноћом закључити: (1) да је овај наставак постао рефлексацијом полугласника, али (2) није јасно да ли је то свуда његов континуант или супституант" (Симић 2002: 372).

Обличка једнакост ГЛмн. карактеристична је за дијалекте зетско-рашког типа, као и за одређене призренско-јужноморавске (гдје се уопштио облик на $-a$ ), али је забиљежена (са ширег подручја) и у споменичкој грађи почев већ од старословенског језика. На подручју зетско-рашког дијалекта у највећем дијелу изједначили су се генитив и локатив множине. У говорима са посебним рефлексом полугласника и са очувањем или замјеном $x$ обичан је наставак -bx (cêл $\bar{a}^{e} x$, гӧдине $\left.e^{a}\right)$,,али има и говора, као што је црмнички, гдје је мјесту $x$ изгубљено (се̂л $\bar{a}^{e}$, гӧдине $\left.{ }^{a}\right)$. Тамо гдје је $b>a$, завршетак је - $\bar{a} x$, или $-\bar{a}^{1}$. Акценат ових облика је генитивни. У великом броју оближњих говора (Бока, Озринићи, сјеничко-новопазарски крај, итд.) Лмн. изједначен је са ДИ, облицима на -ма (Ивић 1985: 164).

У корпусу који је обухваћен нашим радом, можемо рећи да је присутан синкретизам генитива и локатива множине, с тим што се наставци локатива уопштавају и у генитиву (процес је у току), док обрнутих случајева нема.

2.1.1. Лмн. је риједак у нашој грађи, између осталог и због тога што се за локатив уопштава акузатив (седам је примјера на - $a x$, заступљене су именице женског рода, осим у једном примјеру; пет је примјера на -(u)ex: три м.р., два именица ж.р., што може бити утицај о̆-промјена). Нијесмо забиљежили примјере са генитивним наставком. Нпр.:

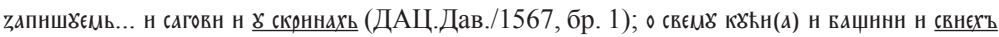

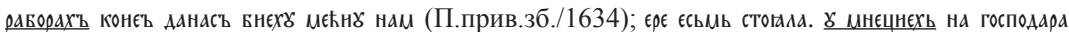
$\left(\Pi / 1593\right.$, бр. 13). ${ }^{2}$

2.1.2. У Гмн. ситуација је сложенија: или остаје стари генитив, тј. наставак је полугласник, или се уопштавају облици на $-x$, што би упућивало на укрштање потенцијала генитива и локатива. У нашем корпусу забиљежено је

\footnotetext{
${ }^{1}$ У Црмници имамо -ӓ, а у Бјелопавлићима -āa, мада се тамо на крају ријечи већином чува $-x$ (видјети: Стевановић 1935: 66; Пешикан 1965: 146; Милетић 1940: 401-402; Вујовић 1969 : 218).

${ }^{2}$ Разрешење скраћеница: П - манастир Прасквица, ДАЦ - Државни архив Цетиње, ДАБ - Државни архив Будва, Дав. - Давидовић (породична збирка Давидовић), Грег. - Греговић (породична збирка Греговић), Див. - Дивановић (породична збирка Дивановић), прив.зб. - приватна збирка.
} 
око 150 примјера са старим генитивним наставком и око 220 са локативним наставком, на $-x$.

2.1.2. А. Осим што је примјера са старим генитивним наставком знатно мање у односу на број примјера са $-x$, овај тип је и лексички ограниченији. Углавном се јавља од назива за новчане јединице (на што отпада двије трећине примјера) и уз бројеве и друге мјерне јединице: од толар забиљежено је 30 примјера, од дукат преко 20, од либра преко 30, остале новчане јединице 15 примјера. Што се осталих лексичких јединица тиче, стари генитив забиљежен је 10 пута од добро („имање, иметак”), по 4 пута од властела, племе, парта, три пута од Турковић, појединачни примјери од синоваи, земља, ебук, литар, баштина, фелон, хаљина, во, поклад, стимадур, говедо, шестак, ден, сестра, маслина, Млеци, сић. Дајемо дио корпуса:

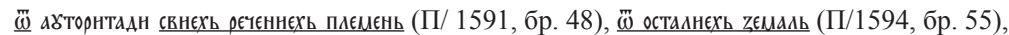

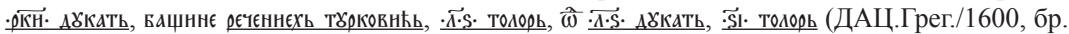
9), 㒸 $\cdot \vec{H} \cdot$ А

2.2.2.Б. Генитив на -х забиљежен је у више од 200 примјера. Најчешће се јавља наставак -ахь, у више од 150 примјера; -ьхь преко 30 примјера; -єхь 8 пута; -нхь 8 пута.

Наставак -ах могао је бити наслијеђен (од $\bar{a} / j \bar{a}$-основа), настати вокализацијом полугласника (код $\breve{l}$-/̌̆-/сугл.-основа), бити добијан аналошки (уопштити се код осталих основа). Јавља се код именица ж.р., али и код именица

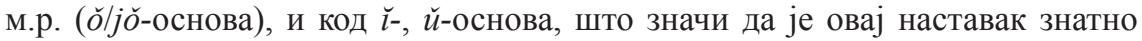
проширио поље своје употребе. Наставак -ех је могао настати вокализацијом

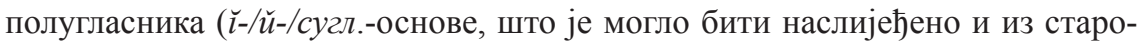
словенског језика, или, што је сигурније, настати вокализацијом полугласника карактеристичном за овај говорни ареал), а могао је настати и аналошки (према -ем, - што је у овом случају мало вјероватно). Наставак -их углавном је карактеристичан за й-основе, при чему су облици на -их могли настати комбиновањем потенцијала из Гмн. и Лмн.

У Паштровским исправама, у нашем корпусу, наставак -ах забиљежен је од свих основа, као и наставак -ьхь, а такође и стари генитив. Употреба једне од форми најчешће варира од писара до писара, код једних се употребљавају или преовладавају једне форме, код других друге. Употреба једне или друге форме може се довести у везу са употребом полугласника: код оних писара који имају $а$ наспрам полугласника у јаком положају (и $а р$ за $p$ вокално) присутан је (или знатно преовладава) наставак - $a x$, док код оних који пишу ь (пишу га и уз $p$ вокално), преовладавају (или се доминантно употребљавају) стари генитив или наставак -ьхь. Нијесу честе исправе у којима налазимо $e$ као континуант полугласника, а у оваквим исправама се јавља углавном наставак -ех у генитиву.

Наставак -ахь је најчешће одлика исправа које су писали канцелари (збора Паштровића), посебно је овај наставак одлика канцелара Ивана Жинтилице (који је написао највећи број исправа које су ушле у наш корпус). Тако, од канцелара, Иван Жинтилица употребљава скоро без изузетка -ахь (46 при- 
мјера, ь>d); Нико Никошић (-ахь: 30 пута; ь>d; 5 пута стари Г); потом и Стево Жинтилица (-ахь: 18; 2 пута стари Г; -нєхь 3 пута; једном пєрпєрєх). Дајемо дио корпуса:

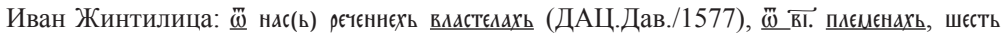
мнеховахь (П/158(1), бб, или 108). У Исправама овог писара редовно је а наспрам старог

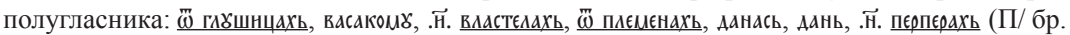
$48,1591)$. Слично је и код осталих писара.

У Исправама гдје се доминантно употребљава наставак -ьхь пише се и полугласник (код игумана Дионисија наставак -ьхь налазимо 9 пута; -ахь 4 пута и то у каснијим исправама, и у тим исправама је $а$ најчешће наспрам старог полугласника; једном је писан стари генитив). Слично је и у још неким исправама, у њима се такође пише полугласник, пише се и уз $p$ вокално.

Нпр., игуман Дионисије: пєть кварьтьхь zємлє (П/ 1529), кьда, смь, тьн, врьня, крьстнћа, АОБрь, ج・ ГрошьХь, АрьжьХь, єсьмь, сьАа, сьмъ (П/1599, бр. 164). Сличан је однос и код осталих писара који доминантно користе -ьхь као генитивни наставак, нпр.: вьсакому, вольнь, тєстамєньть,

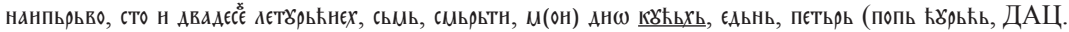
Грег./1597, бр. 2), итд.

Полугласник је најчешће писан и у исправама које карактерише стари генитивни наставак, нпр.:

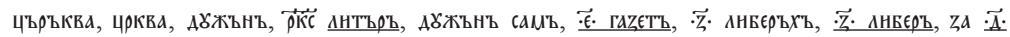

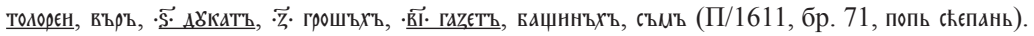

Наставак -єхь забиљежен је 8 пута. У истим исправама среће се $\epsilon$ као континуант полугласника (иако не увијек досљедно). Писари су различити, што значи да овај континуант није био риједак у говору Паштровића у овом периоду:

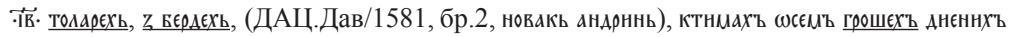
(П/1638,бр.165, укъ), по рнечн паретехъ (ДАЦ. Грег./1655, бр. 17, попъ маръко мбъншша).

Са завршетком -нєхь забиљежили смо 12 примјера и то од именица на -ија (съднєх 7 пута, лєтชрьћнєх 4 пута, једном воћнєх). Овај облик може бити утицај замјеничко-придјевске деклинације (типа овијех, добријех), заједнички дио -иј- могао је повући за собом једнакост:

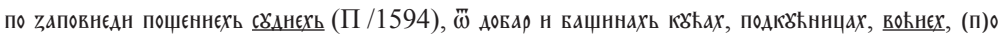

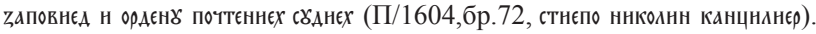

Наставак -их јавља се (осим у једном примјеру) код 1̌-основа:

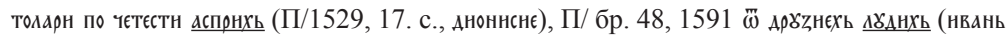

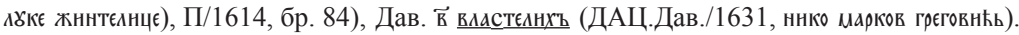

Дакле, корпус Паштровских исправа 16/17. вијека показује да је извршен синкретизам ГЛмн., наставци по поријеклу локативни потискују генитивне. Нема примјера за употребу генитивног наставка у локативу. Стари генитив (са полугласничким наставком) измиче пред локативним наставком на 
$-x$, и знатно је рјеђи, уз то је и ограниченији у употреби, како што се лексичке разуђености тиче тако и морфосинтаксички (чешћи је уз бројеве и мјерне јединице). Употреба наставка повезана је и са изговором и писањем полугласника: писари који као континуант полугласника имају а користе, у принципу, наставак - $a x$, док писари који пишу полугласник употребљавају наставак -ьхь, или стари генитив са наставком -ь, док они писари који имају континуант $e$ за полугласник имају редовно наставак -ех у генитиву. За ову прилику нијесмо успјели да истражимо стање у 18. и 19. вијеку што би показало даље правце развоја наставка у генитиву. Према начелним истраживањима, видљиво је да се смањује фреквенција употребе генитива са наставком -ь, наставак на - $x$ се шири. У досадашњем корпусу нема примјера губљења сугласника $x$ у овој морфолошкој категорији, док ће таквих примјера касније бити. Наставак - $a$ јавља се знатно касније, као и наставак -е, што може бити посљедица различитих фактора, утицаја и кретања. У говору Паштровића, према Миодрагу Јовановићу, у генитиву (локативу) множине „постоје три наставка $-\bar{a}\left(b^{a}\right)$,

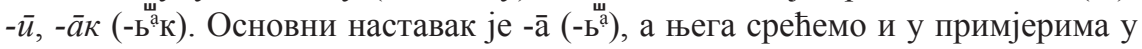
којима је у сродним говорима обичније - $\bar{u}$ (у говору сјеверног сусједа Црмнице, на примјер), па и умјесто -й у књижевном језику” (Јовановић 2005: 253). Стање у Исправама у 16/17. вијеку, упоређено са стањем у говору, показује да су се облици без $-x$, а са $-\bar{a}\left(-b^{a}\right)$ уопштили касније (а према нашим начелним испитивањима у другој половини 19. и у 20. вијеку).

2.3. У историји српског језика, након губљења двојине као семантичке категорије, двојинска једнакост датива и инструментала повукла је за собом једначење ових падежа у множини, „датив и инструментал множине находе се у кругу утицаја двојинских падежа тих наставака" (Белић 2000: 358). Ширење наставка -ма може се претпоставити већ у 14. вијеку, „напоредо са њим иде и могућност напоредног јављања наставка -м и -мa, -мu; - и, и -ма (-мu)” (исто), дакле напоредно (у једном времену) јављање и опстајање (свакако са неједнаком фреквенцијом) у дативу како старих наставака датива множине тако и наставака ДИдв., те наставака Имн., односно јављање тих истих наставака и у инструменталу. Код именица мушког и средњег рода дошло је (из комбинације - $и$ из инструментала, -ом/-ем из Дмн., те -ома/-ема из ДИдв.) до формирања нових облика -им и -има, што је све забиљежено у споменичкој грађи (Белић, исто). То је резултирало уопштавањем двојинских наставака у већини српских говора, поготово прогресивнијих, или до задржавања неких од старијих форми у појединим говорним ареалима. У говору Паштровића извршен је синкретизам датива и инструментала (и локатива), уопштен је наставак на -ма (Јовановић: 301). Како је стање што се тиче ГЛ у 16. и 17. вијеку, а на основу Паштровских исправа као важног свједочанства, видјели смо из претходног дијела рада. Локатив је обличком једнакошћу везан са генитивом. О процесима у вези са падежним синкретизмом ДИ такође су нам важан показатељ Паштровске исправе.

2.3.1. У Дмн. код именица женског рода пронашли смо само наставке -ама, код именица мушког и средњег рода преовладавају стари наставци, а у појединачним примјерима среће се и нови наставак -има. 
За женски род нијесмо пронашли велики број примјера (свега три: од именица иркава, ближика, кћер; у питању су двије кћери и двије цркве што је такође могло утицати на употребу ових облика), али у сва три примјера је наставак -ама:

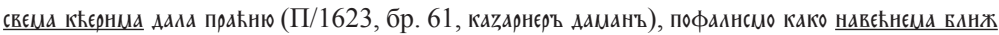
нкама $\bar{\omega}$ парте (П/1603. Див., стнеПо ннколнн канцнинер).

Међутим, од именице судија/судја (5 примјера) јављају се само облици на -ам, дакле стари множински:

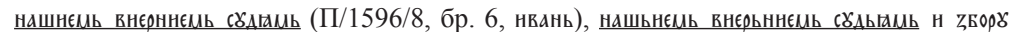
Фдь паџровнћь (П/1634, бр. 119). ${ }^{3}$

У мушком роду (за средњи нема примјера) углавном се употребљавају стари облици на -м (забиљежено је 7 примјера, на -ом/-ем/-ьмь, од именица: стимадур, синовац, брат, Каиковић, Вукмировић, манастир 2 пута), осим у једном примјеру, синовцима (дакле, формиран је нови облик на -има, настао двојинско-множинским укрштањем).

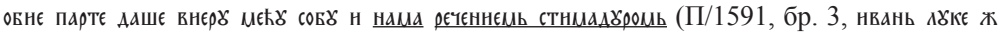

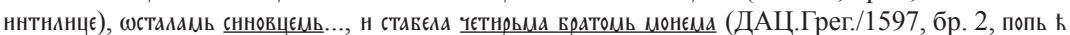

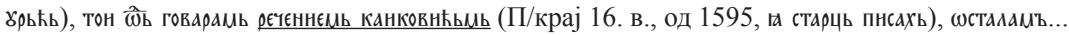
Браћн вакцнровнћєщъ (П/16-17. в., недатирано, бр. 121, попь сћєпань).

Забиљежен је и један примјер на -и (инструментални наставак, а да је множина у питању показатељ су конгруентни атрибути) сєАєћн -в. властєлє...

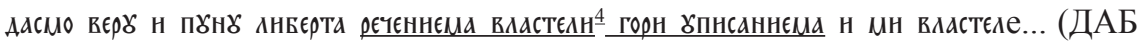
Суђ./1656, нво попа грєговнћа).

Већ у најранијим сачуваним исправама срећу се и нови облици на -има, мада су мање фреквентни од старих множинских облика (забиљежено је 5 примјера: од синовац 2 пута, од манастир 2 пута, динар једном). Нијесу ријетки случајеви да се у истим исправама напоредо срећу и једни и други облици.

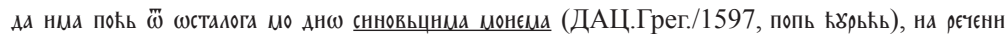

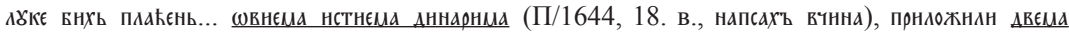
манастнрнца вашн старн... (П/1678, бр. 26, ннко кълача).

2.3.2. У инструменталу су фреквентнији стари множински облици у односу на датив.

Од именица женског рода забиљежени су облици на -ама (чиме се инструментал слаже са дативом, што би говорило да се двојински облик раније

\footnotetext{
${ }^{3}$ Именица судија мијења се по аิ-основама, конгруентни атрибут је у мушком роду: почттнн

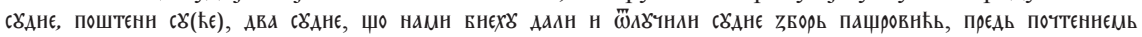

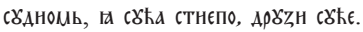

${ }^{4}$ Ова именица забиљежена је у једнини као властелин, а у множини и у мушком и у женском роду: властеле/властели (множина). 4 властеле, 12 властелах (најчешће), 8/6 властелах, 2 властелина, 2 властеле, 3 властели, властели...
} 
уопштио код именица женског рода). Није забиљежен велики број примјера, свега три, један од маслина, два од именице парта:

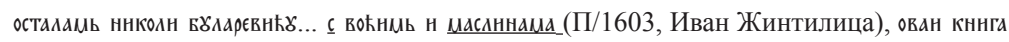
вн Партама оглашєна (П/1645, бр. 58, ннкошнћ по рнечн парат).

Од именица судија/сyђа срета се (за разлику од датива) само наставак -ама. Ова именица је фреквентна, забиљежен је 21 примјер, сви су са предлогом пред: суђама 6 пута, судијама 14 пута, сљћнама једанпут. Дајемо дио корпуса:

нZаєZє Прдь нама вншє пнсаннєма с૪ћама (ДАЦ.Дав./1590, бр. 4), Аа нестъ вєденнє како прєАъ пощєннєма съднама (П/1611, бр. 39, стнепо жннтнлнца).

Именице са значењем парности (некадашња „слободна двојина”, „када се два дијела приписују једном лицу”, Белић 2000: 287), задржале су у Исправама старе двојинске наставке (забиљежено је од именице ноге 10 примјера, од очи 10 примјера, уста 1 примјер), без обзира на то што се у већем броју случајева односе на више лица, тј. имају значење множине. То су случајеви када се „именица са слободним дуалом приписује множини субјеката или предмета, дакле, при тако званој употреби дистрибутивног дуала" (Белић 2000: 290), и у том случају се већ у старословенском језику среће употреба неких од ових именица у множини, образује се множина од великог броја јединки, односно од једнине, ако су именице имале једнину (Белић, исто). У Исправама се често употребљавају именице рука и нога и то у устаљеним конструкцијама:

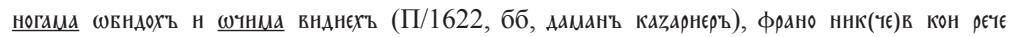
зстниа свонема (П/1654, бр. 69 , поп карсто).

Што се тиче именица мушког и средњег рода, преовладавају облици са старим инструменталним наставком (на -u). Од именице свједок инструментал је са наставком -и (забиљежена су 23 примјера), осим у једном примеру, сви су са предлогом пред. Дајемо дио корпуса:

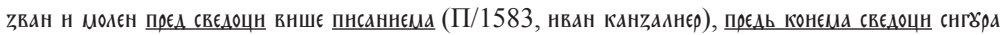

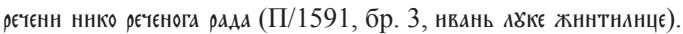

Највећи број примјера је са наставком -и у Имн., а од осталих именица забиљежено је 18 примјера (од стимадур 4, новачићевић и динар по 2; разлог 3, дарвојевић, турковић, калућер, поп, братучед, прокарадур и властелин по једном):

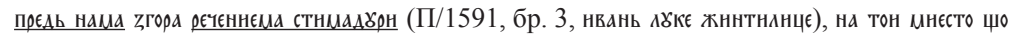

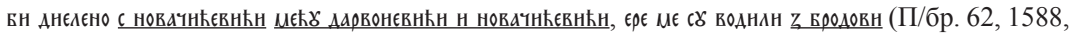

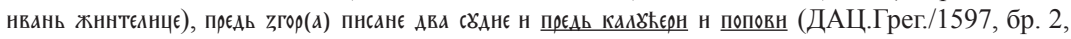
попь ћбрьћь), стнгнєМь з АНнарН свонеща (П/1651, бр. 254, попь карьсто).

Инструментал са наставком -ма рјеђе се употребљава од именица мушког (и средњег) рода (8 примјера, 7 пута је употријебљен наставак -има, 
једном -ијема: у питању су именице живот, добро, динар, властелин, пут, манастир):

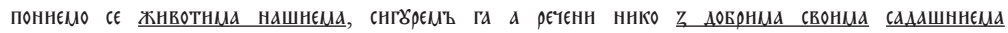

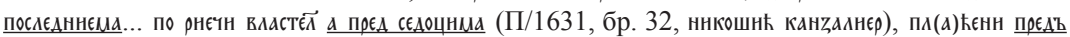

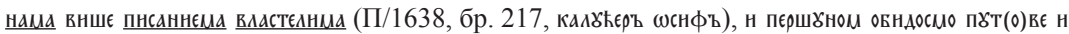
Пбтовнща прнлнкУ... (П/1645, бр. 58, ннкошнћ), прндожнлн двєма манастнрнща вашн старн (П/1678,

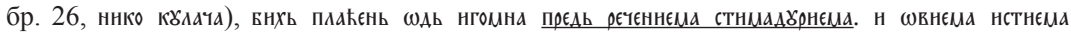
дннарнма (П/1644, 18. в., напсахъъ вчнна). ${ }^{5}$

У једном примеру забиљежен је необичан наставак -оме: ю ннкш вљъковъ Ааровахь дн (ДАЦ.Дав./1588, бр. 3, Ан(ннснє).

Дакле, у ДИмн. употребљавају се напоредо облици на -ма (по поријеклу стари двојински), потом облици множине: у инструменталу на -и (облици старог Имн., нема примјера за употребу облика датива умјесто инструментала ), а у дативу на -м (облици старог датива, осим у једном примјеру гдје је на мјесту датива употријебљен инструментал са наставком -u). Занимиво је да се код именица женског рода и у дативу и у инструменталу употребљавају облици на -ама (по поријеклу стари двојински), што би значило да се синкретизам ова два падежа у множини раније уопштио код именица женског рода. То може бити условљено тиме што је код именица женског рода прихваћен облик двојине као готов, без измјена, док је код именица мушког и средњег рода дошло до формирања новог наставка (насталог комбинацијом множине и двојине).

3. Према нашем корпусу, у 16. и 17. вијеку, у Паштровским исправама заступљена је једнакост генитива и локатива множине, односно датива и инструментала. Једнакост није доведена до краја. У локативу и генитиву множине у употреби су наставци локатива множине на $-x$, али, уз то, опстају (иако мање фреквентни) и облици старог генитива (са полугласником на крају). И у дативу и у инструменталу множине срећу се исти наставци, на -ма, по поријеклу двојински (-ама у женском роду) или наставци настали двојинско-множинским укрштањем (-има у мушком и средњем роду), али се, уз то, срећу и стари наставци датива у дативу (на -м, мада је у једном примјеру забиљежен и инструментални наставак -u), односно инструментални у инструменталу (наставак -u), осим код именица а̂-основа гдје смо забиљежили једино наставак -ама.

\footnotetext{
${ }^{5}$ И код личних замјеница 1. и 2. лица двојинске форме су чешће у употреби у односу на именице, нарочито у инструменталу: У дативу је сљедећи однос: нама 4 пута, нам 2 пута; вама 3 пута, вам 2 пута, једном је забиљежен облик по поријеклу инструментални у функцији датива - вами, а у инструменталу: нама 25 пута, нами 3 пута; вама и вами по једном.
} 


\section{ЦИТИРАНА ЛИТЕРАТУРА}

Алексић 1939: Радомир Алексић, Извјештај о говорима Паштровића, Годишњак Задужбине Саре и Васе Стојановића VI, Београд, 17-20.

Белић 2000: Александар Белић, Упоредна словенска лингвистика 1, Изабрана дела Александра Белића, том 2, Београд: Завод за уџбенике и наставна средства.

Брозовић/Ивић 1988: Далибор Брозовић и Павле Ивић, Језик српскохрватскиххватскосрпски, хрватски или српски, Загреб: Енциклопедија Југославије, ЈЛЗ.

Вујовић 1969: Лука Вујовић, Мрковићки дијалекат, СДЗБ XVIII, 73-398.

Грицкат 1975: Ирена Грицкат, Студије из историје српскохрватског језика, Београд: Народна библиотека Србије.

Трифуновић 2001: Ђорђе Трифуновић, Ка почецима српске писмености, Београд: Октоих.

Даничић 1858: Ђуро Даничић, Историја облика српског језика, Београд.

Ивић 1985: Павле Ивић, Дијалектологија српскохрватског језика. Увод у штокавско наречје, Нови Сад: Матица српска.

Јовановић 2005: Миодраг Јовановић: Говор Паштровића, Подгорица: Универзитет Црне Горе.

Милетић 1940: Бранко Милетић, Црмнички говор, СДЗб IX, 211-663.

Младеновић 2008: Александар Младеновић, Историја српског језика. Одабрани радови, Београд: Чигоја штампа.

Пешикан 1965: Митар Пешикан, Старочрногорски, средњекатунски и љешански говори, СДЗБ ХV, [5] 294.

Решетар 1907: Milan Rešetar, Der štokavische Dialekt, Wien.

Ружичић 1926: Гојко Ружичић, „Развитак српскохрватског генитива плурала на -â", Slavia V/2, Praha, 213-232.

Симић 2002: Радоје Симић, Морфонолошки проиеси у српскохрватском језику. Њихови узроции и последице, Београд: Јасен.

Стевановић 1935: Михаило Стевановић, Источноцрногорски дијалекат, Библиотека ЈФ V, Београд, 1-129. 
Jelica Stojanović

MORPHOLOGICAL FEATURES OF THE GENITIVE AND LOCATIVE, DATIVE AND
INSTRUMENTAL PLURAL NOUNS IN THE PAŠTROVIĆ MANUSCRIPTS
$\left(16^{\mathrm{TH}}\right.$ AND $17^{\mathrm{TH}}$ CENTURIES $)$

Summary

The paper discusses dual-plural overlappings in the genitive/locative, and in the dative/locative plural in the Paštrović Manuscripts from the $16^{\text {th }}$ and $17^{\text {th }}$ centuries. As attested by our corpus, in the $16^{\text {th }}$ - and $17^{\text {th }}$-century Paštrović Manuscripts the frequency of the genitive and locative plural, i.e. of the dative and instrumental, is equal. The equality does not show fully. The locative and genitive plural take the locative plural endings in $-h$, but the forms of the old genitive (with a semivowel at the end) persist parallelly. The same endings are found both in the dative and instrumental plural: they include $m a$, etymologically dual (-ama in the feminine gender), or endings derived through dual-plural crossing (-ima in masculine and neuter), but it is also possible to see the old dative endings in the dative (with $-m$, although one example also features the instrumental ending $-i)$, that is, the instrumental endings in the instrumental (ending -i), except in the â-stem nouns, where we registered only the ending -ama.

Key words: Paštrović Manuscripts, genitive and locative plural, dative and instrumental plural, Paštrović speech, distribution of endings, case syncretism. 